\title{
ESSAY
}

\section{Introduction: Looking for Black Miami}

\author{
Donette Francis ${ }^{1}$ and Allison Harris ${ }^{2}$ \\ ${ }^{1}$ University of Miami, US \\ ${ }^{2}$ Clemson University, US \\ Corresponding author: Donette Francis (d.francis@miami.edu)
}

Conceptualizing Miami as the "Hemispheric South" captures the hemispheric collision of peoples, practices, and prejudices that have transformed understandings of whiteness, Blackness, Latinx and power in this city. The essay argues that Black migrants are foundational to Miami's hemispheric history. Using the life writings of Black academics, it demonstrates that a hemispheric angle on Miami revises understandings of U.S. migration, Civil Rights, and the sounds of Blackness. The city speaks in different grammars of Blackness, thereby rendering more layers of the Black experience legible, usable, and cautionary. Miami's Black histories speak to our present moment where global migration is rapidly becoming the defining issue of the era. Because Miami's history presaged a wider set of civil rights reversals for Black Americans, the city's Black history provides a new lens on familiar questions of race and incorporation thus enabling us to see a different narrative arc of the United States. Reframing Miami in terms of Black hemispheric movement reorients key debates in Black Studies, Caribbean Studies, American Studies around race, migration, whiteness, and civil rights.

Keywords: Black Miami; Hemispheric; Migration; Creole Civil Rights; Sonic Blackness

I can't think of what it means to be black and not think of this polyglot city -Tera Hunter

Black migrants are foundational to Miami's hemispheric history. ${ }^{1}$ A city built on the speculation of real estate, transportation, banking, agriculture, and tourism, Miami has only recently registered in national public policy conversations around Blackness or scholarly theorizations of Black aesthetics. ${ }^{2}$ This invisibility has been due, in part, to tendencies that privilege histories and resonances of plantation slavery in the South and the Great Migration out of the South. Both approaches elide other histories of Blackness that emerge from this city that bears the indigenous name for sweet or big water. ${ }^{3}$ There are signs of tentative steps toward greater recognition; the current national reception of the work of Tarell Alvin McCraney has garnered visibility for one segment of Black Miami. Along with Barry Jenkins, their 2017 Oscar-winning film, Moonlight, explored their Liberty City neighborhood, and more recently McCraney's OWN Network series, David Makes Man, centers the agricultural town of Homestead in relation to other northern inner-city

\footnotetext{
${ }^{1}$ For hemispheric positioning of Florida in general, Miami and Key West specifically, see respectively: Cassanello and Murphree; Shell-Weiss; M. Campbell.

2 Notable engagements include: Dunn, Connolly, Bush, Boyce Davies, Rose, Keenan et al. See also The Color of Wealth. Lopez approaches the aesthetics in relation to Afro-Cuban America in his reading of various cultural productions that memorialize and mourn of the 1979 police beating that lead to the death of Arthur McDuffie and again in his analysis of Black rap appropriations of Scarface.

${ }^{3}$ Kokomoor argues that historians have erroneously characterized the relationship between the Seminoles and the Africans on the Florida frontier through the conceptual framework and language of southern plantation slavery; and consequently, have missed the contrastingly operative Native American agricultural patterns. Dunn records that from 1804 enslaved Blacks were brought to Key Biscayne and formed a century-long alliance with the indigenous Seminole Indians (7). Today, the recent commissioning of a mural of Miccosukee historical heroes in the midst of the Wynwood Arts district is one attempt by the local Miccosukee Tribe of Indians to contest their historical erasure in Miami and inscribe their presence into one footpath of this tourist landscape, thereby increasing awareness and environmental advocacy to safeguard the Everglades as their home.
} 


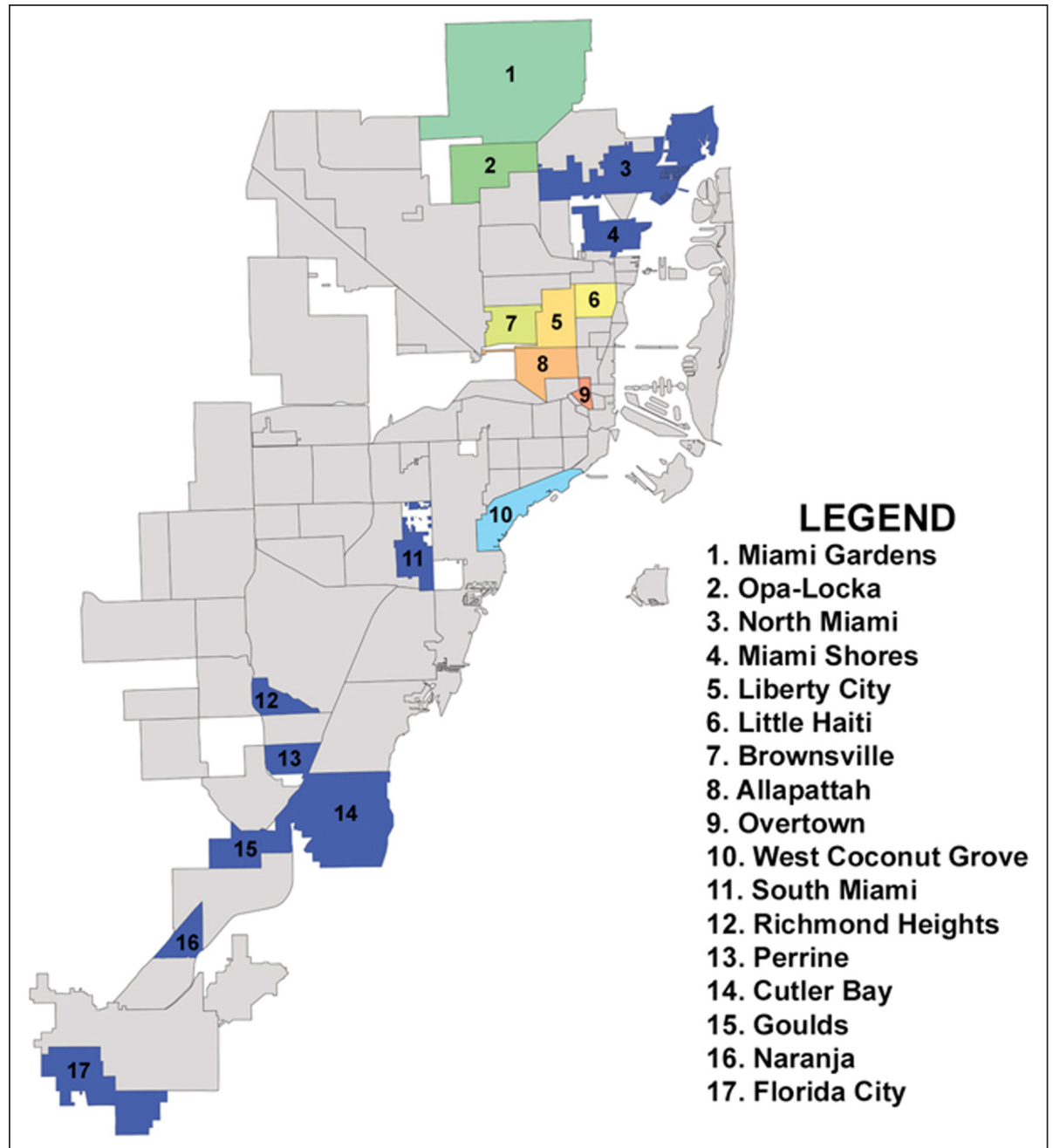

Miami's Black neighborhoods are spread throughout the length of the county. Colors correspond to neighborhoods represented by the issue's authors, while navy represents other Black Miami neighborhoods. Map courtesy of Germane Barnes.

communities of Miami-Dade County. ${ }^{4}$ But these engagements with the city's Blackness are only the surface of the deep Black multi-generational migrant and immigrant histories constitutive of Miami's multicultural and hemispheric composition, where $93 \%$ of the current foreign-born population are from the Americas. ${ }^{5}$

The mid-twentieth century historical juncture contributed greatly to the making of contemporary Miami, but this period is often narrated through the lens of the Latinization of Miami while absenting (or bracketing) the deeply-embedded Blackness against which that Latinization came to be defined. ${ }^{6}$ This special issue, "Looking for Black Miami," foregrounds the life writings of Black scholars who have called Miami home, and whose histories intersect with the city's transformative mid-twentieth century creolization process. On April 20, 2018, seven leading Black intellectuals convened at the University of Miami: Tera Hunter, Juana Valdes,

\footnotetext{
${ }^{4}$ Arguably, there have been earlier fleeting moments where the nation was obliged to see Black Miami: the June 19, 1990 Senate obscenity hearings on the lyrics of the Miami-based rap group 2 Live Crew; the dominance of the University of Miami's (mostly Black) football team from the 1980s to the early 2000s (Corben and Spellman); and the 1990 battle around Nelson Mandela's visit, where the local Cuban exile community ensnared Mandela's meeting with city officials in pro-Castro and pro-Communist rhetoric, compelling local Black activists to respond by launching a national boycott of Miami hotels, costing the city millions in revenue (Mohl "On the Edge).

${ }^{5}$ Miami's diversity is skewed toward its Hispanic population: 63\% percent of the county's residents are Hispanic, $18 \%$ are nonHispanic whites, $15 \%$ are Black; and $71 \%$ of its residents speak a language other than English at home. A further breakdown of the foreign-born population reveals 47.3\% Cuba; 7\% Colombia; 6.2\% Nicaragua; 6\% Haiti; 3.3\% Honduras; 3.2\% Venezuela; $2.9 \%$ Dominican Republic; 2.6\% Peru; 2.1\% Jamaica; 2.1\% Mexican. 2015 Statistical Atlas for Miami Dade County.

${ }^{6}$ See Portes and Armony, Portes and Stepick, Niman, and Aranda et al.
} 
Kevin Quashie, Edda Fields-Black, Jemima Pierre, Nathan Connolly, and Anthony Jack. ${ }^{7}$ Comprising generations of Black Miamians, these scholars represent varied disciplinary perspectives such as history, sociology, anthropology, literary studies, and the visual arts. Together they hail from recognizable Black Miami neighborhoods ranging from Allapattah, Brownsville, Little Haiti, Liberty City, Opa-Locka, Carol City, and West Coconut Grove as well as The Orange Bowl ${ }^{8}$ and Miramar. ${ }^{9}$ Born between 1960 and 1984, their life histories both coincide and collide with pivotal years marked by political and civil rights struggles that were simultaneously local, national, and hemispheric: the 1959 Cuban Revolution and its consequent out-migration; the 1968 race riots in Liberty City while the Republican National Convention took place on Miami Beach corresponded with a summer of rebellion in Black neighborhoods nationally; the 1980 race riots in Liberty City after the acquittal of four white officers (one of whom was white Cuban) for the severe beating that lead to the death of unarmed Black motorist Arthur McDuffie; and, the 1980 Cuban Mariel and Haitian boatlifts. ${ }^{10}$ These events brought forth issues of racial inequality in Miami that have produced populations persistently shaped by the conditions of migration and exile, and the confrontations, contestations, and accommodations that have accompanied becoming Miamian.

"Looking for Black Miami" argues for a historically-rooted ethos of seeing and hearing a textured Black vitality that has been omnipresent in the cityscape if one knows where to look and how to listen. It draws on the voices of those whose lived experiences show the vibrancy and heterogeneity of Black Miami. As such, the essays in this collection contest research trends that seem only to find in Miami's Black neighborhoods crime-ridden places of danger, deficits, and sociological wrong turns. ${ }^{11}$ They challenge as well assets-mapping of chocolate cities in the U.S., where Miami is referenced, but not explored. ${ }^{12}$ Instead, the life writings of these intellectuals unveil an intergenerational, multi-dimensional, and hemispherically-oriented Black life-world. Their histories reveal institutions and structures of sociality emergent from international and intranational migration patterns, polyvocal linguistic registers, and inter-ethnic neighborhood networks. The opening epigraph by the historian Tera Hunter captures the multilayered quality of Miami's Black geographies when she states that for her Blackness is synonymous with this polyglot city. Centering Blackness animates a different social and political geography of Miami, which in turn produces a different social and political geography of the United States. At the same time, repositioning Miami generates a different social and political geography of Blackness, one that transcends the limits of the nation-state. The intricate interpretations of these intellectuals' multivocal and multifaceted Miami unfold in the following

\footnotetext{
${ }^{7}$ Donette Francis, Convener: "Mapping Creole Miami: Black Intellectual and Artistic Formations," University of Miami, April 20, 2018. Tera Hunter (1960) is the Edwards Professor of American History and Professor of History and African American Studies at Princeton University; Juana Valdes (1963) is Associate Professor of Printmaking in the Department of Art at University of Massachusetts, Amherst; Kevin Quashie (1971) is Professor of English and Africana Studies at Brown University; Edda Fields-Black (1972) is Associate Professor of History at Carnegie Mellon University; Jemima Pierre (1973) is Associate Professor of Anthropology in the Department of African American Studies at University of California, Los Angeles; Nathan Connolly (1977) is the Herbert Baxter Adams Associate Professor of History at Johns Hopkins University; Anthony Jack (1984) is Assistant Professor at the Harvard Graduate School of Education. Jack's essay presented on that day is not included in this collection; but is published as Jack, Anthony Abraham. 2019. "On Her Behalf: James Baldwin, Family, and Educational Inequality." Common Reader. 4(1):19-38.

${ }^{8}$ While not traditionally understood as a Black neighborhood, Valdes identifies her neighborhood as The Orange Bowl. Today it would be demarcated as East Little Havana.

${ }^{9}$ Connolly names himself a Miami imposter since he grew up just to its north in Broward County but attended college on the northern edges of Miami-Dade County at St. Thomas University.

${ }^{10}$ Again, Miami native and scholar of Afro-Cuba, Antonio Lopez carefully points out that in the McDuffie case, one officer's ethnicity as white Cuban has been submerged but is very important to understanding the context of place. Miami was marred by riots again in 1982, 1989, and 1991 after police shootings of unarmed Black citizens. Lopez argues that not naming officers' white/Latinness or white Cubanness in incidents of police violence enacts another form of violence in making it invisible. Following Lopez, one can then trace a genealogy that leads to George Zimmerman's white Hispanic identity traced to his Peruvian mother-and his killing of Trayvon Martin. See also Marable for contemporaneous 1980 reflection.

${ }^{11}$ Portes and Armony position Cuban exceptionalism as the driving force that transformed Miami into the city it is today. Primarily through the metaphor of the growth machine of capital development, they argue that Cubans from the 1960s and 1970s changed the scope of the city from Southern to global. As it relates to representations of Blackness, their analysis reifies outmoded theories of the "subculture of poverty" and the "tangle of pathologies" that criminalizes, ghettoizes, and victimizes Black communities with no discussion of how federal programs for housing, business development, and education as it related to this generation of Cuban refugees helped to reproduce structural and economic inequalities and segregation.

${ }^{12}$ In their 2018 book Chocolate Cities: The Black Map of American Life, Marcus Hunter and Zandria Robinson redraw the United States into a six-zoned map of Blackness defined by different regional recastings so that all places south of Canada is the South and must be understood within the context of a U.S. Southern Black diaspora. Hunter and Robinson's reconceived Black US map breaks out into 6 regions: Out South, West South, Mid South, Up South, Deep South, and Down South. According to this map, Miami falls within their categorization of Down South, but by their metrics which necessitates the consolidation of political and economic power, Miami is not a conventional chocolate city.
} 
essays and revise understandings of U.S. migration, Civil Rights, and the sounds of Blackness. Miami's Black histories speak to our present moment where global migration is rapidly becoming the defining issue of the era. Because this hemispheric city speaks in different grammars of Blackness, it allows for more layers of the Black experience to be legible, usable, and cautionary. In addition, because Miami's history presaged a wider set of civil rights reversals for Black Americans, the city's Black history provides a new lens on familiar questions of race and incorporation thus enabling us to see a different narrative arc of the United States.

\section{"Who Set You Flowin"?": Migrations and the Black Making of Miami ${ }^{13}$}

A Blackness that exceeds the nation-space has been integral to Miami's formation. The city's hemispheric location and imperial position challenge received histories of Black migration patterns by exposing movement into the South from within the U.S. and from other places across the Americas. "Looking for Black Miami" and the Black life-writings in this issue distinguishes Miami as both an early and late Great Migration Southern destination. As such, this issue both complements and extends earlier scholarship best captured in the work of Farah Jasmine Griffin, where in identifying the push and pull factors that led Black migrants to leave the U.S. South, or to later return to the South, Griffin underscores the ubiquity of "critical migration narratives" in Black American literature and cultural productions. Where Black Miami locations like Overtown were once understood colloquially as the Harlem of the South, we extend this spatial metaphor to situate Miami as the Harlem of the Hemisphere. Since the city's 1896 incorporation, contingent upon the 182 authorizing votes cast by Black migrants from the Bahamas, North Florida, Georgia and South Carolina, the city has been a hemispheric hub for Black migration. ${ }^{14}$ Positioning Miami as the "Hemispheric South" underscores that it has been and continues to be a national and international destination for Black migrants, and captures as well the overlapping zones of the U.S. South, Global South, the greater Caribbean and Latin America. ${ }^{15}$

A hemispheric angle on Black Miami's early history brings into view the long-standing entanglements between Bahamians and African Americans. Settled well before Miami-proper, antebellum Key West was a significant port city and trade route to the Caribbean with a large population of white Bahamians, who migrated after the 1834 British emancipation of the enslaved population, and Black Bahamians, who followed the growing seafaring-related industries (Anderson; M. Campbell). By the 1890s, Bahamians, especially Black Bahamians, started moving north to Miami, and in addition to providing votes for incorporation, they built the city's physical infrastructure alongside regional Black migrants. From 1896 to 1920, Miami experienced a demographic boom as the city grew "from a few hundred to almost 30,000"; and, Black West Indians, most of whom were from the Bahamas, numbered 4,815 by the period's end (Anderson 75). ${ }^{16}$ Black Bahamians moved from Bahama Village in Key West, the oldest Black settlement in South Florida, to Coconut Grove, which they inhabited from as early as the 1880s. Black Bahamians transplanted their cultural and architectural practices that are still evident in this oldest continuously Black-populated Miami neighborhood (Anderson 75). ${ }^{17}$ Today, the West Grove houses the last of these generational legacy Black families actively trying to stave off rapid gentrification, dispossession, and displacement in this sole-remaining parcel of Black Coconut Grove. These formative late nineteenth-century Black Bahamian narratives resonate in contemporary local histories of Black Miami and provide the essential historical backdrop for contextualizing recent Bahamian immigration in the aftermath of the catastrophic Category 5 Hurricane Dorian in September 2019.

Dominant twentieth-century narratives of the long Great Migration of African Americans in the United States (1916-1960s) foreground the movement away from the U.S. South to established cities in the Northeast, industrialized cities in the Midwest, and to young-growth cities on the West Coast. Push factors

${ }^{13}$ Farah Jasmine Griffin, "Who Set You Flowin'?": The African-American Migration Narrative.

14 Dunn records 182 Black votes in the total 367 (57).

15 Situating South Florida as "Down South," Hunter and Robinson rightly underscore the systemic racism of the United States and the southern practices Black migrants brought with them wherever they settled. Unfortunately, however, other equally important regional geopolitics are obscured.

${ }^{16}$ It is also important to note a Jewish presence in Miami as early as the 1896 signing of the city's incorporation. Mohl identifies 25 Jewish signees ("On the Edge").

17 Architect Germane Barnes argues that Black churches in Miami are a direct descendent of traditional Black vernacular building methods, which elevated porches and first floors out of necessity due to climate. By raising the elevation, the buildings are passively cooled without the intervention of air conditioning. Moreover, their buildings can resist potential disaster from rising tides or hurricane flooding. Only recently have architects and architecture branded the terminology as climate-resilient design, but Barnes argues that Black builders have been doing it since they began constructing their own homes in the 1700s. See Barnes and also Dunn and Burch. 
such as Jim Crow laws, racialized violence, and poor economic conditions led to a massive migration out of the South and the redistribution of the Black American population. Yet, with Miami's relative youth and foundational Black presence, Black Southerners were also pulled away from sites of their former enslavement to seek labor opportunities within the city's expanding transportation, agricultural, and service industries. The period of the 1930s through the 1960s saw paradoxical growth opportunities for Black laborers in Miami despite the fact that the city had "the highest degree of residential segregation among more than one hundred large American cities" (Mohl "Whitening Miami" 338). Notwithstanding, or precisely because of, such relentless residential segregation, Overtown, a neighborhood originally designated in the late 1890s by railroad magnate Henry Flagler for Miami's Black laborers, developed its own vibrant identity with businesses, churches, civic organizations, and night clubs created to meet the needs and desires of these Black residents. Miami's ongoing twentieth-century segregation continued to confine Black communities to particular areas of the city such as the development of Liberty City (in the northwest) and Richmond Heights (in the southwest). ${ }^{18}$ Black Miamians persisted in establishing a dynamic Black life-world that highlighted Miami's links to the greater South and broader hemispheric centers of commerce and culture by shaping port-city industries, organizing labor unions, and building self-owned businesses. But even as they made accommodations for racial exclusions, Black communities and Jewish neighborhoods as well were subjected to the heavy presence of the KKK, racialized violence, and bombings. Such physical acts of racial terror throughout the 1950s and 1960s accompanied by white flight whenever Black families moved into historically white neighborhoods led Miami to remain (and arguably still remains) persistently Jim Crow (Mohl "South of the South?"). ${ }^{19}$

Black migrants continued nonetheless to speculate on possibilities for the Black good life; and moving to hemispheric Miami often translated as movement into a diverse Black middle-class that comprised of a range work from doctors to well-placed domestics. As a fourth generation Miamian, Edda Fields-Black's family represents the geopolitics of Miami's Black migration story: nineteenth-century Bahamian immigrants on her mother's side and twentieth-century African American migrants on her father's side. Her maternal greatgrandfather arrived in Key West in the 1890s and worked harvesting natural-grown sponges from coral reefs around barrier islands in the Florida Straits (Pierce). Her maternal great-grandmother worked as a domestic, and her desire for their children to secure a good education set the family "flowin" to Miami, where they settled first in Overtown and later in Brownsville. When Fields-Black's paternal grandparents left coastal South Carolina for Miami in the 1940s, the city's Black community represented a slightly more diverse and urban Black experience. They transplanted their Gullah Geechee heritage, thereby introducing into Miami's early Black diasporic formation a unique tradition reflective of both the West African coast and the lower Atlantic coast of the U.S. Similarly, representing the later years of the Great Migration, Tera Hunter's parents moved to Miami in the 1950s following older family members from rural northeast Georgia-seeking both labor opportunities and a more urban experience. For both Hunter's and Fields-Black's family members, professional and social networks became vehicles to class mobility: Hunter's father became Vice President of the International Longshoreman's Association Local 1416 union, which had been chartered and headquartered in Overtown since 1936; her mother held leadership roles in the historic Mount Zion Baptist Church and was awarded "Woman of the Year" in 1977; Fields-Black's family members were educated at prestigious Black colleges and universities across the South; her father attained his JD from the University of Miami Law School in 1977; and her mother, Dorothy Fields, established the Black Archives History and Research Foundation of South Florida in $1977 .{ }^{20}$ By the time Hunter and Fields-Black were coming-of-age as young women in Miami (from the 1970s through 1980s), they were firmly rooted in the Black middle-class, in which churches with their youth ministries as well as sororities and tennis programs became places where Black girls and young women were socialized into practices of social mobility made possible by their institutional navigation of different areas of the city.

\footnotetext{
${ }^{18}$ John Stuart, "Liberty Square: Florida's First Public Housing Project." Initially white-inhabited farmland, the 1937 large-scale development of Liberty Square Housing Project, was a signature of President Franklin Delano Roosevelt's New Deal. This public housing complex led first to the construction of a race wall in Liberty City to separate Black from white residents, and then to the subsequent white flight. In southwest Miami-Dade County, the Richmond Heights subdivision was purchased, founded and developed as middle-class housing for returning Black WWII veterans by white veteran pilot Captain Frank C. Martin (Garrett and Modkins).

${ }^{19}$ Mohl suggests that the increase in KKK violence can be attributed to the retirement and relocation from Atlanta to Miami of the Klan's national imperial wizard James A. Colescott in 1945 ("South of the South" 5).

${ }^{20}$ Parallel Lives. Featuring Dorothy Fields and Arva Moore Parks, produced by Jack Kelly, South Florida PBS Presents, 2010.
} 
These Black Miami origin stories have shaped their intellectual pursuits. We might, for example, connect in Hunter's 1998 first book, "To 'Joy My Freedom": Southern Black Women's Lives and Labor After the Civil War, the recognition of the migratory pull of postbellum Atlanta as a New South city to her family's intra-south migration patterns. We might also trace her keen contemporary analysis of tennis that provokes readers of her Twitter feeds to insist that she write a book about tennis to her Miami roots playing tennis in Moore Park. Likewise, Fields-Black's scholarship on rice production linking the coastlines of Georgia and West Africa as well as its recent translation into her co-production of the libretto, Unburied, Unmourned, Unmarked: Requiem for Rice, is guided by her coastal South Florida experiences of her Gullah Geechee heritage and the musical talents developed playing her "beloved flute" in the South Florida Youth Symphony. ${ }^{21}$

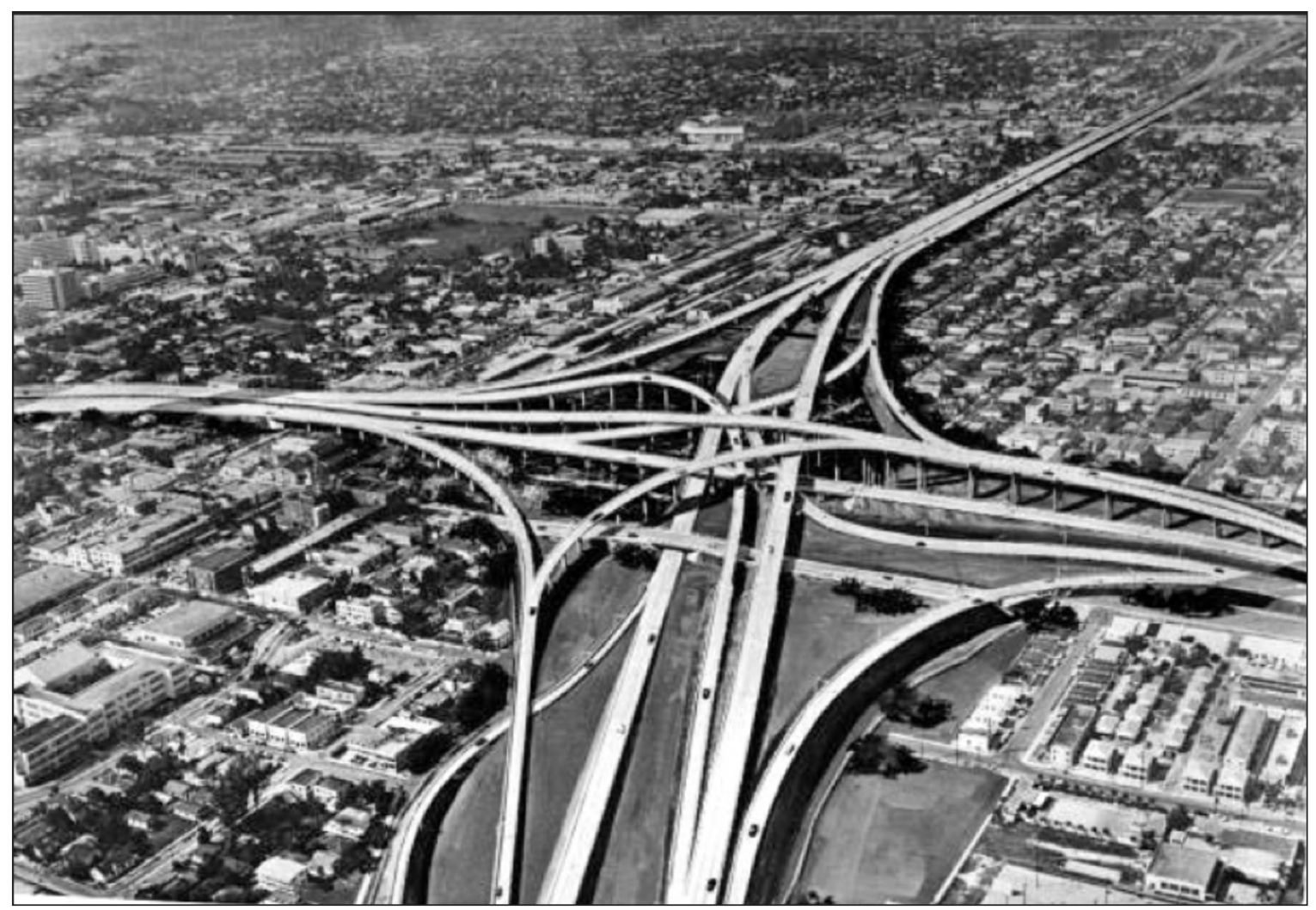

The massive interchange that decimated Overtown. Photo circa 1960.

\section{Creole Civil Rights}

Miami's Civil Rights mobilizations were earlier than many official national timelines, and the city's tropical location gave these activations its unique character that advocated for access to public spaces of leisure. Pointedly, as early as 1945 activists organized wade-ins at segregated beaches in Miami and throughout the state of Florida (Bush). ${ }^{22}$ The city's Civil Rights leaders envisioned and practiced interracial coalition building and activism. They enlisted and joined forces with other racialized minorities, like Jewish migrants who also experienced Jim Crow segregation with restrictive racial covenants prohibiting them from purchasing properties on Miami Beach north of $4^{\text {th }}$ Street (Mohl "South of the South"). From April through the fall of 1959, for example, Black and Jewish activists in Miami's interracial branch of the Congress of Racial Equality (CORE) staged sit-ins at lunch counters across downtown Miami. These protests were in advance of the February 1, 1960 Woolworth's store lunch counter sit-ins in Greensboro, North Carolina that are often credited with laying the groundwork for sit-ins across the South (Mohl, "South of the South;" Rose). Moreover, in the

${ }^{21}$ Fields-Black, Deep Roots: Rice in West African and the African Diaspora; Executive Producer and Librettist (with composer, John Wineglass, and filmmaker/director, Julie Dash) of "Unburied, Unmourned, Unmarked: Requiem for Rice." www.requiemforrice.com.

${ }^{22}$ Reverend Edward T. Graham of Mount Zion Baptist Church (Tera Hunter's minister), led the first "wade in" ever conducted in the United States. Indignant about conditions of racial exclusion, he led a group of Blacks protestors over the causeway to Bakers Haulover where they stood in the water until forced to leave by police. www.sfltimes.com/news/rev-edward-t-graham-and-dr-vond-mizell-two-local-legends-made-history-in-south-florida. 
summer of 1959, CORE leaders chose Miami as a training site for non-violent direct action, organizing the Miami Interracial Action Institute, which was attended by local Miami activists such as Patricia and Priscilla Stephens as well as national figures like Martin Luther King Jr. and Jackie Robinson. ${ }^{23}$

While such interracial coalitions were being established, the local climate grew contentious, as new immigrants from the hemisphere and migrants from within the nation converged in this young Jim Crow city and shifted hegemonic Anglo-centric practices of whiteness. Miami's central role in tensions between Cuba and the United States meant that impending U.S. legislative promises to Black citizens were redirected to immigrating Cubans, especially wealthy white Cubans, as beneficiaries of Cold War politics. In a similar way, with capital from established businesses from the U.S. northeast and the Caribbean, Jewish migrants were able to develop hotels, as well as other properties and businesses, thereby reshaping Miami Beach as a desirable yearround residence and vacation destination as well as constructing a longstanding ethnic financial foothold in the city (Mohl "On the Edge"; Bettinger-Lopez). This post-1959 moment, therefore, significantly creolizes the once static Black/white divisions of U.S. Civil Rights to expose multiple ethnicities within communities identified through Blackness and Latinidad as well as the many routes of Jewishness (through Europe, the U.S. northeast, and the Americas) rooted in the city. The legacies of Miami's mid-twentieth century history persistently reveal that where Jewish and white Latinx migrants have been able to remake a city whose restrictive racial covenants once excluded them, Black migrants and residents have not had sustained institutional or capital gains. Instead, despite their longstanding generational presence dating back to the late nineteenthcentury, Blacks in Miami remain structurally vulnerable to city-wide exclusions and dispossession.

An abridged version of the mid-twentieth century creole civil rights story in Miami exposes that on the heels of the 1964 Civil Rights Act, the city experienced the emergence of what would become a white Latinx hegemony that displaced earlier forms of institutionalized Anglo-white racisms. Middle- and upper-class Republican white Cubans who left in the earliest part of the Revolution brought their social capital and generational wealth into Miami, purchased homes in the area surrounding $8^{\text {th }}$ Street that would eventually become Little Havana, and later in affluent neighborhoods like Coral Gables. Elsewhere, the senior author describes this Cuban acculturation model as a process whereby white Latinness (both largely and initially Cuban) eclipsed and then toppled an Anglo-American identity by making claims to the city's financial, political, and cultural institutions. ${ }^{24}$ This white Latinx incorporation amplifies the structural vulnerabilities of Blackness, and lays bare the generational lack of access to capital. Therefore, as citizens of the hemisphere met up in this relatively young city with a briefer Anglo-American hegemony, a decisive shift occurred in the 1980s when the cultural wars crystalized Miami's acculturation into a Spanish-dominant, bicultural city. Effectively, the upper- and middle-class white Hispanic population normalized the idea and practice of a cosmopolitan hemispheric creole whiteness rather than assimilating successive generations of immigrants into a U.S.-national Anglo model of "becoming American" (Francis). Fissured by inequalities based on race, immigration, class, and language, by the end of the 1980s Miami would become functionally Hispanicized, and Black residents would feel despair and betrayal by both federal and local institutions. These entangled hemispheric histories of Civil Rights struggles and their aftermaths in Miami, as they impacted relationships between new and established immigrants, migrants, and native residents, offer an important lens from which to understand the settlement politics of such less-theorized spaces of U.S. Southern migrations, and what it portends for future race relations nationally. That this particular polyglot history of white Latinx hegemony could be constructed at the very moment of the supposed breakthrough for Black people demonstrates the systemic fiscal and ontological vulnerabilities of Blackness. The legacies of this post-1959 moment foreshadow dogged Black exclusions. And as such, it is a key moment where finding Miami can help us find both Blackness and the U.S. anew.

Less resourced Black Cubans, who were also present in the 1970s migratory wave, experienced the city's already deep-rooted housing segregation as a barrier to their inclusion in Cuban enclaves. Thus, they often blended into Black Miami neighborhoods comprised of multi-generational African American migrants and Afro-Caribbean immigrants. ${ }^{25}$ Juana Valdes's Black Cuban migration is at once quintessential and perceived

\footnotetext{
${ }^{23}$ See the September 1960 issue of CORE-lator for more on the 1960 Interracial Action Institute held in Miami. www.crmvet.org/ docs/core/core6009.pdf. Tananarive Due and Patricia Stephens Due, Freedom in the Family.

${ }^{24}$ This characterization is distinct from Portes who frames the Cuban migrations acculturation in reverse. By naming cosmopolitan hemispheric creole whiteness, Francis keeps in the frame the various kinds of Latin whiteness that accede to power in the city and maintain their connections to the various centers of power in the Caribbean and Latin America.

${ }^{25}$ See the forthcoming work by Danielle Pilar Clealand and Devyn Spence Benson, Black Migration into a White City: Power, Privilege and Exclusion in Cuban Miami. See also Aja, Gosin, Benson.
} 
to be exceptional when viewed against the pre-1980s' waves of immigrants. Valdes recounts her mother's skepticism of the Cuban Revolution, and her consequent decision to leave Cuba in order to ensure that her sons would not be forced to serve in the Cuban army or attend the Revolution's new escuela al campo agricultural youth camp initiative. Coming from Cuba during the last years of the Freedom Flights in 1971, Valdes's Black Cuban identity contradicts the standard narrative of white Cubans with financial and political ties in Miami being the singular first-generation refugees. Moreover, the Valdes family disrupts the more commonly-circulated story of Black Cuban immigration into Miami as a phenomenon of the 1980s and the Mariel Boat Lift. Valdes is careful nonetheless to underscore that her family felt isolated from both Cuban and Black Miami communities well into her young adulthood. Unlike Fields-Black's and Hunter's families, who came to Miami during a growth period for the Black working- and middle-classes, the Valdes family, with the additional Spanish language barrier, found less opportunity for class mobility. To provide for their family, Valdes's mother initially worked in the farms of the Redlands and Sweetwater in south Miami-Dade County and later moved to the northeastern edge of Little Havana, where she worked as a seamstress in sweatshops. The race and class politics of white monied Cubans expediently translated to the entrenched Black/white racial divisions in the U.S. South. ${ }^{26}$ Valdes asserts that money facilitated faster assimilation amongst the mostly white Cuban émigrés since those who could afford private schools for their children and classes in English quickly integrated into the power systems of the burgeoning city and over time reshaped its institutions and infrastructure to match their own fiscal investments. But the ethnic and linguistic contours of Cubanness reveal it to be a whiteness of a different kind, demonstrating roots and routes both through Europe and the hemisphere. Together then, the parent generation of Hunter, Valdes, and FieldsBlack illustrate the conditions of possibilities and impossibilities for Black Miami under Jim Crow.

For these Black Miami intellectuals, the politics of race and class were often reflected in their education and its impact in shaping their identities. As federal legislation challenged Jim Crow, our authors' experiences of the city overlapped with the Miami-Dade school system's transition from segregation to integration to re-segregation and the changing sounds and characteristics of the city's whiteness. In 1959, Orchard Villa Elementary, located in what was then still the predominantly white neighborhood of Liberty City (segregated by a race wall), was the first integrated school in Miami-Dade County, effectively five years after Brown v. The Board of Education in 1954 prompted the federal mandate for school integration (Miami Herald). However, bussing throughout the state of Florida did not start until 1970, which meant a decadelong state-wide integration process (Winsboro and Bartley). As the oldest members of this cohort, Hunter and Valdes experienced this transition in real-time. Valdes keenly observes that Cubans were read as white in the Black/white integration paradigm and were therefore bussed from majority Cuban neighborhoods into predominantly Black schools like Booker T. Washington High School in Overtown. From as early as Pre-Kindergarten, Hunter experienced bussing; however, in this first instance, it was to attend a private Black school, Jackson Toddler Inn, where she would have been educated amongst the city's Black elite. She later attended the neighborhood public school, Allapattah Elementary, where she was able to walk to school with her siblings. By fifth grade, her local public school was integrated. Where before Hunter had been exclusively educated by Black female teachers, now she experienced being taught by a white female teacher for the first time. In 1972, Hunter was bussed from her neighborhood in Allapattah to Kinloch Park Middle School in the white residential neighborhood of Flagami. Later, when presented with the option to remain within the district of her predominantly white junior high school, Hunter chose her neighborhood school, Miami Edison Senior High School, which would become the site of new segregation in the 1980s. Born twelve years after Hunter and a decade after Valdes, Edda Fields-Black's generation was the first in her family to attend fully-integrated schools in Miami-Dade County in the 1980s. At the elite Carrollton School of the Sacred Heart in Coconut Grove, the majority of her classmates were from Latin America's nouveau riche, many exiled in Miami, and as she describes, "from every corner of Latin America, particularly Cuba, Venezuela, Nicaragua, Columbia, and Argentina." While Latin Americans were in the majority, there was a recognizable Black immigrant population, "largely from the Caribbean, Haiti, the Bahamas, and Jamaica." Here, Fields-Black points to the less considered middle- and upper-class Caribbean immigrants also making a home in Miami during this period. In this school setting, "African-American, Anglo, and Jewish students were definitely in the minority."

\footnotetext{
${ }^{26}$ It is important to underscore that the majority of Black and brown people in Miami live lives of financial precarity. See Color of
} Wealth, Miami. 
Where Fields-Black describes the convergence in Miami of the hemisphere's middle- and upper middleclasses, Jemima Pierre's account of Haitian girlhood in the late 1980s and early 1990s chronicles the reentrenchment of segregation through de facto segregation. Influenced by white flight and divestment, her neighborhoods demonstrate the reproduction of racial borders aligned with class and ethnicity. Between 1988 and 1990, an influx of Haitian immigrant children were enrolled in the already predominantly Black American-populated Miami Edison Middle and High Schools, leading to the negative "hyperBlack" designation and the colloquial naming "Haiti High." While this was Pierre's zoned school, she carefully situates how Black immigrants like her parents sought to give their children a better chance by relocating to North Miami Beach. In this new academic setting, her classmates were white, mostly Jewish students "from upper-class Jewish communities." While they would socialize in public, rarely was she invited to their homes and vice versa. As the youngest member of this cohort, being a student in Miami-Dade County's public and private schools in the mid-1990s through 2000s provided Anthony Jack the lens to think about educational structures that would guide his future sociological research. Transferring from his designated public school as a Coconut Grove resident to Pinecrest's elite Gulliver Preparatory School in his senior year of high school highlighted for him the deep racial and class discrepancies in the city. Jack's research dissects differences between what he defines as the privileged poor and the doubly disadvantaged, distinguishing the ecology of homes and educational systems to offer more nuanced ways of understanding the category of lower-income college undergraduates and how distinctions of schools make a meaningful difference in life outcomes ${ }^{27} \mathrm{At}$ our convening, Jack recounted the moving story of advising his brother to relocate his niece from their neighborhood school in the Black Grove to attend an elite preparatory school, a move that Jack himself helped to subsidize with his graduate stipend, motivated by his intimate knowledge of the difference such schooling makes. Together then, the educational experiences of these Black academics elucidate the fine distinctions of integration in Miami from the 1960s through 2000. Their personal reflections underscore the local processes of racial formation-both within whiteness, Latinness, and Blackness-that must be filtered through the city's hemispheric orientation, generational migration, country of origin and ethnicity, class, and spatial divisions.

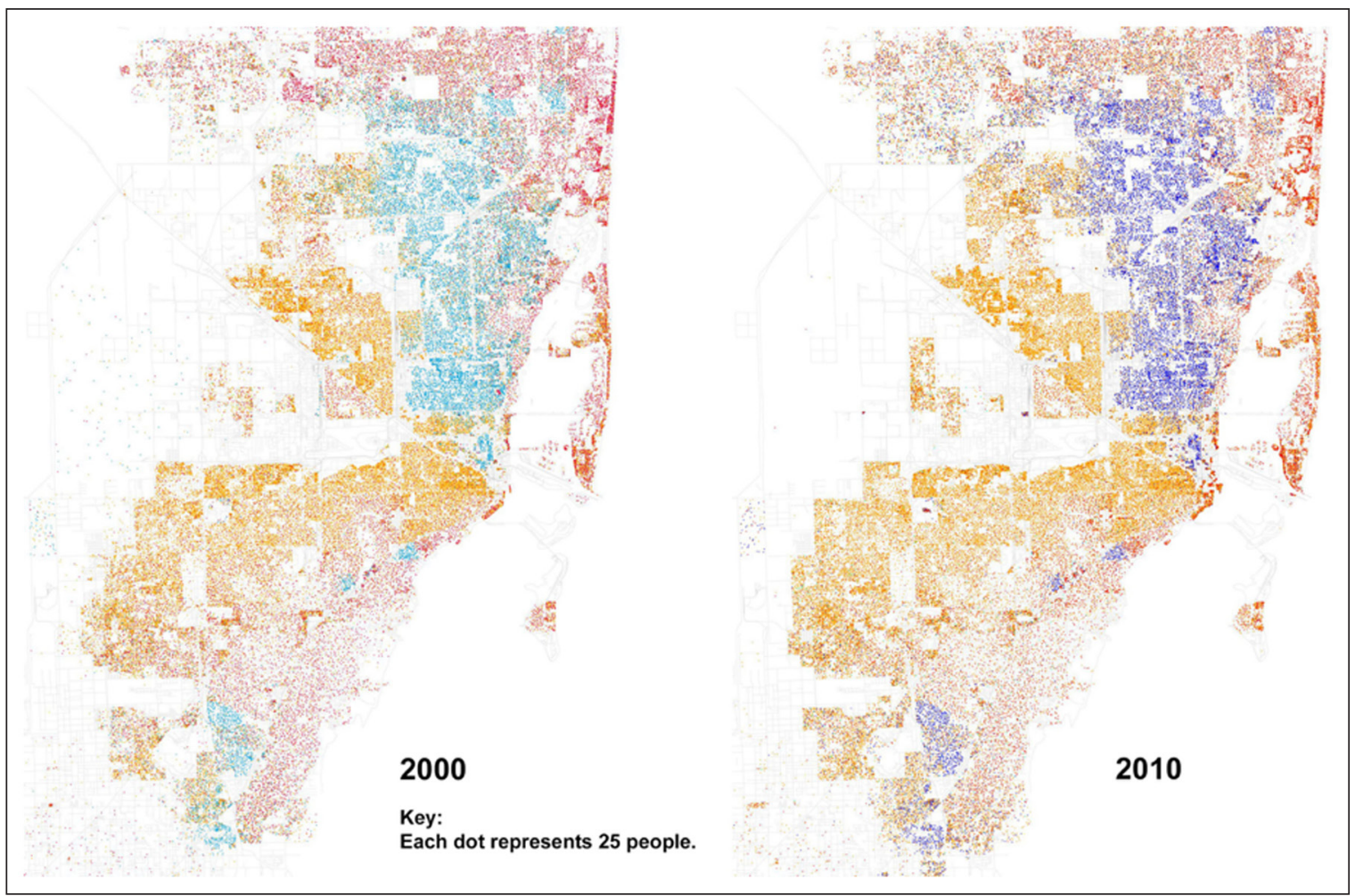

These maps capture the population density and changing racial divides in Miami from 2000 to 2010. The data is pulled from United States Census; thus, races are self-identified. Key: Red-White; Blue/TealBlack; Orange-Hispanic; Green-Asian; Gray-Other. The maps visually illustrate the concentration of Black Miami in just a few neighborhoods. Maps created by Eric Fischer.

\footnotetext{
27 Jack, The Privileged Poor: How Elite Colleges are Failing Disadvantaged Students.
} 


\section{Black Sonic Edges ${ }^{28}$}

Local manifestations of the hemispheric collision of peoples, practices, and prejudices in Miami also make audible the manifold layers of Blackness as expressed in languages and accents, music and dance. Throughout their essays, these Black thinkers carefully map the spatial edges of Miami neighborhoods in which they were raised to reveal spaces of proximate intimacies, where from its margins the threat and promise of mixture exist, and where bodies are within sight and sound of difference. These sonic recollections capture the spatial and temporal edges of Black Miami's mid-twentieth century hemispheric creolization process as a Southern U.S. town, a Caribbean city and a numerically- and linguistically-dominant Latin American metropolis. Their composite narratives of Black Miami's ethno-linguistic formation challenge the city's Spanish-English dichotomy as well as Spanish as solely representative of Miami's multiculturalism. Instead, the collective processes of coming to voice reconstructed in these essays render accents and Kreyol/Creoles as equally important markers of Black cosmopolitanism. As such, Miami's Black linguistic soundscape invites critical consideration of language diversity inside Blackness-recall again, Hunter's polyglot city-in order to capture English, Spanish, French, Kreyol, the many Anglophone Creoles, as well as the varied accents of both African American migrants and Black Caribbean immigrants. ${ }^{29}$ Whereas practices of cosmopolitan hemispheric creole whiteness have not resulted in more equitable ways of living together across the creolized color line, Black sonic ecologies demonstrate both the hazards and opportunities of living with and within Black difference.

The diverse Black sonic edges carved out in these essays underscore the negotiations of heterogenous forms of creolization. Poignantly, each essay opens with the very physicality of spatial movement-from one neighborhood to another within Miami, or from a Caribbean country to Miami-and its shaping impact on the sounds of Black identities. Tera Hunter charts her family's movement in the 1960s and 1970s from a rented apartment in Liberty City to purchased homes in Allapattah and later El Portal, a predominantly white suburb in North Miami-Dade County. She writes: "My childhood was spent in primarily two neighborhoods: Allapattah, which then was the southern edge of Liberty City, and El Portal, on the edge of Miami Shores." Her family's intra-city relocations illustrate neighborhoods and schools in transition from early Black middle-class housing when they first arrived (as one of the few Black families) to consistent white flight by the end of their first year in-residence. Where before Hunter attended neighborhood schools in Allapattah, for middle school she was bussed to Flagami where she became "more aware of Cuban American language and culture through peers." That she identifies a "Cuban American language and culture" and not simply Spanish as a sensibility suggests that Cubans largely made up her growing perception of the city's Hispanic population. Her recollection rightly marks the numerical presence of Cubans in 1970s' Miami, where in 1960 the overall Cuban population in the United States was 79,000, and by 1970 in Miami alone they numbered over 350, 000. ${ }^{30}$ Her ethnic framing of Spanish also captures that in the local pre-1980s Black imaginary, Cubans often represented the Latinx population in the city. Hunter emphasizes that in her present encounters with people outside of Florida, they often remark that she does not "sound" like someone from Miami. Presumably, such a statement signals the limited expectation of a Caribbean accent rather than an awareness of Miami's polyglot Black diversity. This elision underscores that Miami elicits many exclusions: the dominant history of this city as Hispanicized does not have space to include Blackness and dominant histories of Blackness do not have space to include Miami. To that end, this issue helps to decenter both of these myths.

\footnotetext{
${ }^{28}$ From the early 1990s, social scientists have used the edge metaphor to characterize Miami's post 1959 multicultural unfolding. In 1990, urban studies historian, Raymond Mohl described Black Miami as being kept "on the edge of rage and despair" because of "the persistent failure of the system to deliver often promised social and economic improvements-better housing, improved schools, job training, better services-contrasted with the perceived advantages and benefits received first by the Cubans, and later by the Nicaraguans" (53). In 1993, the sociologists Alejandro Portes and Alex Stepick write what has become the classic text about the Latinization of Miami, marked by the precarity of the city's ethnic stew, City on an Edge. In 2018, Portes updates the study with Ariel Armony to characterize the city as "the global edge," now suggesting the shift in the dominance of any particular ethnic group and instead power is diffused. Yet, the elite voices of white Cuban and Latin American business classes are credited with the teleological transformation of Miami. In 1992, the anthropologist Michel-Rolph Trouillot also used the edge as a spatial metaphor to think about the globally marginalized Caribbean spaces and the cultural practices New World Blacks have created from "the edges of the plantations, blurring the logic of an imposed order and its daily manifestations of dominance" (19). Trouillot's perspectival edge is relevant to analyses of Black Miami as we consider what Black Miamians have been able to create against the innumerable odds in which Blackness has been and remains structured in dominance.

${ }^{29}$ Miami's existing Black mosaic is being reshaped by migrations of continental Africans into South Florida, retirees and snowbirds, as well as other transplants from the Midwest and northeast establishing new businesses in Black heritage neighborhoods.

${ }^{30}$ Migration Policy Institute. www.migrationpolicy.org/article/cuban-immigrants-united-states. See also: Susan Jacoby.
} 
Juana Valdes also addresses the presumptions of Black linguistic sound-in this case, what it means to sound like a Miami-raised Cuban. Attending to the intersections of race, ethnicity, and language, her family's 1971 arrival adds an interesting twist on the racialization of urban space. Immediately, the Valdes family confronted Jim Crow racism because "it was really hard to find a place to rent." Linguistically limited to Spanish, they were geographically tied to Cuban enclaves, where they also experienced racial discrimination in housing due to the racial dynamics of anti-Blackness in Cuba itself and its transference into Miami. Valdes describes the need for a Spanish-speaking community as "the only way [her mother] could survivebut no one would rent to us." Thus, as she frames it, "We were on the edge of the edge." Consequently, their first place in Miami was a shotgun house on the northeastern edge of Little Havana. On this block of five to six houses, they formed a community of outsiders with, as Valdes characterizes, "another more mestizo-looking Cuban family from Matanzas and the poor white American families living there." Whereas Black Miamians often tell stories of white flight once they moved into a neighborhood, Valdes's story demonstrates transracial class dispossession that created intimacies. Valdes and her siblings learned English by playing with the poor Anglo-white children of their neighborhood rather than exclusively in formal educational settings. Therefore, when she is greeted with comments that she does not look (race) or sound (non-Cuban-accented Spanish) like someone from Miami, such assertions unwittingly index how Valdes experienced the intersections of race, ethnicity, language, and place within the city and the nation. This outsider status, has nonetheless, provided a double-consciousness-what Valdes describes as being "on the edge forever looking in on [and listening to] multiple societies." In other words, Valdes has been privy to seeing and hearing conversations that express discriminatory insider sensibilities, and her interview points to the pain of living in the liminal spaces between race and ethnicity. Valdes's perspectival edge nonetheless manifests in the materials and content of her art practice that emphasizes the embodied experiences of shifting regimes of power across national boundaries. Her art practice interweaves threads of race, gender, language, and symbol to document and honor her mother's labor history on both sides of the Florida Straits-in Cuba and in Miami.

In her essay, Fields-Black conveys the potency of the sound of Gullah Geechee cultural retention, describing visits to her paternal grandparents' home in Opa-Locka, where she found the Gullah Geechee language communicated between her father and his parents impenetrable. If the sounds of Black identities on her father's side signaled African linguistic retention, then on her mother's side it announced standard English recitations. Fields-Black writes that with their purchase of adjacent properties on two blocks with no fences separating their backyards, her extended maternal family members recreated a Bahamian yard in Brownsville, a neighborhood she delineates as located "on the edge of Hialeah and Liberty City." Miami locals understand Hialeah to be a mostly Cuban and Latinx enclave and Liberty City as a Black neighborhood. By the time Fields-Black comes-of-age in 1980s' Brownsville, this post-world war II Black suburb had become overtaken by "depressed pockets and housing projects." Encircled by the intimacy of a refashioned Bahamian yard, Fields-Black nonetheless felt isolated in her Brownsville neighborhood as she commuted to the elite private all-girls Catholic school in Coconut Grove. Her strict parents, coupled with the all-encompassing efficiency of her family yard, never required her to interact with neighborhood children. As a result, in Black spaces such as The Church of the Incarnation, Jack \& Jill, Buds of Spring, and the debutante society, she was "routinely called an Oreo" (black on the outside and white on the inside) because she spoke "proper, standard English." Thus, rather than places of Black respectability serving as spaces of solace, Fields-Black confesses they were sites of personal antagonism given her socialization on the edges of Miami's multiple middle- and upper-class racial and ethnic cultures. In many ways then, her story refuses any triumphant American or African American story of class mobility and integration.

Kevin Quashie's family's 1985 immigration to Miami from St. Kitts placed them within a cacophonous scene of Blackness in an Opa-Locka apartment complex that housed other small-island immigrants (e.g. from Antigua, Dominica, St. Lucia) and Black Americans. ${ }^{31}$ As a Black English-speaking immigrant, Quashie recalls the various kinds of negotiations, external and internal adaptive strategies, that go largely unremarked upon in same-language-receiving countries with a pre-existing Black population like the United States. Though West Indians speak English, Quashie reminds us, it is a non-American English that can be used to differentiate West Indians from African Americans; and the valuation of good or bad depends on who is doing the discriminating. Quashie opens the essay with a poem written in the summer before $10^{\text {th }}$ grade about the loss of his mother tongue, where wrestling with language was a key feature of his immigrant consciousness. He depicts how it felt to be "unhomed" in language and asks: "What is the relationship between the voice of one's interior and the voice in which one speaks to the world?" To which he answers, "At almost fourteen, I am a child of quiet, silence, solitude-I have a roiling interior but I hardly ever speak out 
loud." Quashie captures the complex interior life-in which speech acts were central-of what it meant to be a West Indian queer boy child coming-of-age in mid-1980s Miami where his social world was composed of other West Indians, mostly from the Eastern Caribbean, Cubans, Haitians, and Anglo-whites. Chronicling the violence of being dispossessed from a "mother tongue," he discloses the various communities to which he yearned to belong but could not speak in the right linguistic register. In his mother tongue poem, Quashie found himself outside many English language communities, including "the black American boyness he so craved, the slick lyric slang that eluded him." Ironically, he settled on performing a public speaking voice "of clear human authority" in imitating that of the foreign white male ABC broadcaster, the Canadian Peter Jennings. This significant grappling with the practices and poetics of quiet during his Miami adolescence would become the crux of Quashie's conceptual-methodological intervention in Critical Black Studies. ${ }^{32}$

Likewise concerned with accents as markers of social integration, Jemima Pierre distinctly recollects that her November 1981 re-unification with her parents (in Miami from Port-au-Prince, Haiti) was met with the danger of sounding Haitian. The precarity of their Black ethnic identity shaped their spatial world as her parents lived in a tiny apartment on NE $81^{\text {st }}$ Street near Biscayne Boulevard "on the very north edge of Little Haiti." Just two blocks south, on $79^{\text {th }}$ Street and Biscayne Boulevard, was the twelve-story INS building that controlled much of their immigrant lives. The family would move further north "to the northern edge of North Miami Beach, to a new city called Miami Gardens, which put [them] close to the line that separated Dade County from Broward County." ${ }^{31}$ This spatial move north inadvertently followed city planners' orchestration to both remove and relocate Blacks from the central downtown business district — a plan in rapid execution today (Mohl "Whitening Miami). ${ }^{32}$ Where her 1981 entrance into Miami was met with an assault for being Haitian, her father's church, Eglise du Nazareen Peniel, served as a space of refuge that allowed young Haitian schoolchildren to gather and form community while continuing to speak in both Kreyol and French rather than suffering the further trauma of losing their devalued mother tongue. Thus, despite its patriarchal strictness and homophobia, Pierre credits her father's church for enabling her to maintain physical and cultural ties to Haiti and her linguistic fluency in French and Kreyol. To survive the daily onslaughts from the larger public-Black, Latinx, and white-Pierre often tried to pass as Bahamian. Her very astute young perception that Bahamian-rather than Jamaican or more recent Anglophone Caribbean immigrants-was a more credible Black ethnic identity to linguistically pass into drew upon the long-standing Bahamian generational presence in which accents would be less discernible in children of the fourth generation. In other words, she chose a Black immigrant identity with such deep roots in the city that a range of possible ways to sound African American-via the Bahamas-had evolved. One can trace Pierre's experiences with the predicament of Blackness as a Haitian in Miami to her scholarship on Ghana, where she turns to a modern, active, cosmopolitan contemporary Ghana to demonstrate that race is not a primordial category in Africa. And, much like Miami's mid-twentieth century multicultural scene, Pierre traces local entanglements of "European empire making," racialization, and racial discrimination in Ghana. ${ }^{33}$

In addition to the racial dynamics of voice manifested in languages and accents, music also reverberates throughout these life writings. The first friend with whom Hunter crossed the invisible afterschool color line to visit in each other's homes was a white classmate whose shared love for baton-twirling brought them together. Their steadfast but segregated musical affections and commitment to the songs of Michael Jackson (Hunter) and Donny Osmond (her friend) meant that their friendship could survive their differently racialized musical tastes. Embedded in Edda Fields-Black's essay is a soundtrack of the intimate growing pains of integration and other local Civil Rights struggles. The elementary school dance just for safety patrols where she "surreptitiously and alone" danced to "Michael Jackson's 'Off the Wall"' exposed the Black isolation of integration. The abrupt ending of her favorite song, "Special Lady" by Ray, Goodman, and Brown, at her sister's "Buds of Spring" cotillion marked the announcement of Arthur McDuffie's death that would spark the significant 1980 race riots and had further intimate resonances since McDuffie's wife and daughters attended her home church. Her lifelong love for merengue music was initiated during her high school years at New Carrollton while dancing to Wilfrido Vargas's "El Africano"-despite its racist anti-Black lyrics. ${ }^{34}$

\footnotetext{
${ }^{31}$ It is important to note that north of Miami-Dade County, in Broward and Palm Beach Counties, the racial logics shift and Blackness becomes more visible and presumably more integrated into the political and financial organs of those counties.

32 See Mohl "Whitening Miami" for this historical displacement, and Gierczyk in this issue for an analysis of the most recent efforts in Little Haiti.

${ }^{33}$ Pierre, The Predicament of Blackness: Postcolonial Ghana and the Politics of Race.

${ }^{34}$ For further context on this popular 1980s' song, see Rivero.
} 
Even with the cross-over success of the Latin sounds of the Miami Sound Machine in the late-1970s and 1980s, for Valdes the essence of cool was located in African American Hip-hop and R\&B music and dress. Her sonic remembrances are of the dominance of African American music on the airwaves: "Earth, Wind, and Fire stayed on the hit charts" and "Luther Vandross's voice became the definition of sexy." Because style and coolness were significant to self-fashioning, Valdes recalls that white and Latinx youth started emulating Blackness. As a young adult in the 1980s, Valdes journeyed into African American neighborhoods in search of hipness: "we found ourselves embracing the afro, the flyness. We looked for places where we could go dance, party, hang out and show off our style. And these places were in the African American neighborhoods." Therefore, in registers such as these, "being Black was not a bad thing. It gave you 'street cred'-a sense of feeling chic and cool." A 1980s Rhythm and Blues soundtrack also structures Kevin Quashie's essay about coming-of-age as a Black "Queer. Caribbean. Miami. Boy." Each section of his three-part essay is sonically punctuated by a song: Billy Ocean's "There'll be Sad Songs to Make you Cry"; The Jungle Brothers, "I'll House You"; and Luther Vandross's "For You to Love." If a younger Quashie felt "unhomed" in speaking American English, then in African American R\&B Quashie found an intimate home-a full-bodied aliveness that he inhabited when singing out loud and rhythmically moving to these songs. The pulsing intimacy of Quashie's relationship to R\&B will remind some readers of Stuart Hall's declaration that at nineteen, jazz put its fingers on his soul. ${ }^{35}$

For Jemima Pierre, her linguistic passing as Bahamian to evade the daily offensives of being Haitian shifted to her becoming adopted into the Jamaican middle-class cultural worlds in North Miami and Carol City, where the sounds and socialities of music pulsated Sunday afternoon dinners. House parties replaced the fellowship of her father's church; French and Kreyol hymns yielded to the homegrown Miami Hip-hop and Reggae music scenes. In this context, Pierre encountered the complexities of Jamaican racial formation and the range of racialized and classed identities housed in the sounds of various Jamaican accents - from Chinese Jamaicans, brownins, and Blacks to their spatialized uptown and downtown, classed inflections. During the late 1990s, Nathan Connolly's first real sojourn into Miami's Black inner-city neighborhoods was motivated by the search for a good DJ for a college party at St. Thomas University in what is now the heart of Miami Gardens. Living in Miramar in Broward County and attending college in Miami Gardens, iconic spaces of Black Miami had an elusive quality for Connolly-marking him as a cultural outsider. But his Liberty City quest for a DJ-who delivered what he describes as the "banging-est party in university history"-not only exposed him to a segregated city but to how Black people made music out of the most "pared-down" resources. This expedition literally changed Connolly's relationship to Miami, as the city would become the principal site and subject of his scholarship, which deciphers the logics of racial capitalism through the city's complex real estate practices. ${ }^{36}$

Clubs and dance floors therefore functioned as transformative coalitional spaces that brought Black Miami together and provided shared ways of being within Black difference. Parsing socio-linguistic differences amongst the various Black ethnic groups became less relevant to the emerging Black music scene, which included R\&B, Reggae, and Hip-hop, especially their local variants. Quashie's coming into aliveness resulted from interacting with the array of Black identities and sexualities on the dance floors of Florida International University's Thursdays-by-the-Bay and the Black gay club, Sugar's. By the time Fields-Black returned to Miami for college breaks, her inland isolation in Brownsville was diminished as she attended the club, Strawberries, in Hialeah-known as the place to go after Hurricanes football games, where Luther Campbell hosted sessions (L. Campbell). Though Hunter offers no soundtrack of the music she listened to while rollerblading with friends on Miami Beach, the boardwalk nonetheless became her metaphorical dance floor as she claimed the right to the once segregated beach for Black female leisured movement.

\section{Speculating on Miami's Blackness: The Essays}

Even though these intellectuals are largely from Black neighborhoods in North Miami-Dade County, the April 2018 convening brought into our collective exchange other South Florida stories in addition to ongoing medical research on Black Miami. Marcelyn Cox, an Associate Dean at the University of Miami's Law School, grew up in Key West during the 1970s and 1980s. She described the affective ties Blacks in Key West had to, and for, Miami and greater South Florida. Although 150 miles to the southwest, Miami's print and broadcast media were their source of news. The Black community in the Keys followed closely and was

\footnotetext{
35 Stuart Hall, interview by Sue Lawley, Desert Island Discs, BBC Radio 4, February 18, 2000.

${ }^{36}$ Connolly, A World More Concrete: Real Estate and the Remaking of Jim Crow South Florida.
} 
"overwrought" by the murder of Arthur McDuffie by the police. Cox recounts that on the morning of the McDuffie riots in May 1980, her mother pulled her out of school in fear that "spurred by the happenings in Miami" a riot could break out in the Keys. ${ }^{37}$ Such social histories expand further south our understanding of the expansiveness of Miami's Black geographies and bring to a full circle the nineteenth-century Black migrations in Key West. Our conversation also included medical research on Black Miami being conducted by Dr. Sophia George and other medical oncologists at the University of Miami Health Systems. Because Florida has the second highest incidence of newly diagnosed cancer and cancer-related deaths in the United States, by looking at Black Miami, with its complex genetic diversity based in the Caribbean, researchers have been able to isolate the large incidents of breast cancer and the prevalence of BRCA1 and BRCA2 mutations among Bahamian women. As such, UM hospital's protocol for breast-cancer screening of Black female patients asks them to self-identify if they are Black Bahamian. This information enables increased screening and awareness of risk in Bahamian natives, immigrants, and descendants-to have an impact on prevention and earlier diagnosis. ${ }^{38}$ That cancer detection for Bahamian women is developed in Miami and not the Bahamas speaks to the city's long engagement with Bahamians as well as its role as the imperial center of the hemisphere-in this case, as it relates to resources for medical research.

By way of conclusion, we return to the double-meaning of speculation. It is both "the forming of a theory or conjecture without firm evidence" as well as "the investment in stocks, property, or other ventures in the hope of gain but with the risk of loss." Our intellectual pursuits rest on the first definition of speculation since the art and science of our academic endeavors is to make hypotheses and then prove or disprove them with evidence of varied disciplinary kinds. Nathan Connolly's concluding essay turns on the second meaning of speculation as he shifts the context to capture the market forces of both the creative and academic industries, especially market demands for scarcity in the art work of the self-taught Black artist from Overtown, Purvis Young. For Connolly, like many others, Miami is a quintessential Caribbean city precisely because local home-grown talent cannot stay within the county lines; instead, their ambitions are nurtured elsewhere. While the reasons are wide-ranging, these talented Black intellectuals are themselves located in what Connolly would characterize as a "Miami intellectual diaspora" in academic institutions outside of Miami.

While formalizing these essays for publication reflects the intellectual labor of the April 20, 2018 convening, it does not convey the emotional labor, ephemerality, and vulnerability of this occasion that brought us together for the first time. Inside what Pierre called the "specificities of [their] stories," was what Quashie commended as the commitment to "stay with the trouble of the truth." Staying with "the trouble of the truth" meant acknowledging that at the city-wide level there is a collective shame and disappointment about the lack of Black consensus politics that might have translated into political victories such as a Black mayor of Miami. In 1970, Hunter's childhood pastor of the Mount Zion Baptist Church, the Reverend Edward T. Graham, was one of the earliest Black commissioners in the City of Miami; and, during his 1972 tenure as vice-mayor, Graham briefly served as interim mayor when then mayor Robert King High died in office. ${ }^{39}$ In many ways then, the 1970s would mark the end of such Black incorporation into the city's political machine-demonstrating a creolized shift that instantiated the inability of Blacks to substantially seize and sustain a footing in the city's political and financial institutions. This fact sets Miami apart from cities like Atlanta or Chicago; instead we might argue that Miami's history foreshadowed a wider set of reversals for Black Americans. On the cultural front, we closed our convening conversations on Moonlight, and dreaming of things to come in the fullest expression of a Black Miami aesthetics in sight, sound, and embodiment.

\footnotetext{
${ }^{37}$ Cox, unpublished paper.

${ }^{38}$ Barreto-Coelho, Priscila, et al. "Differences in Breast Cancer Outcomes amongst Black US-Born and Caribbean-Born Immigrants." SpringerLink, Springer US, 14 Aug. 2019, doi: 10.1007/s10549-019-05403-9.

Donenberg, Talia, et al. "A Clinically Structured and Partnered Approach to Genetic Testing in Trinidadian Women with Breast Cancer and Their Families." SpringerLink, Springer US, 4 Dec. 2018, doi: 10.1007/s10549-018-5045-y.

Lerner-Ellis, Jordan, et al. "A High Frequency of PALB2 Mutations in Jamaican Patients with Breast Cancer." SpringerLink, Springer US, 13 Feb. 2017, doi: 10.1007/s10549-017-4148-1.

Donenberg, Talia, et al. "A Survey of BRCA1, BRCA2, and PALB2 Mutations in Women with Breast Cancer in Trinidad and Tobago." SpringerLink, Springer US, 28 July 2016, doi: 10.1007/s10549-016-3870-4.

Donenberg, Talia, et al. "A High Prevalence of BRCA1 Mutations among Breast Cancer Patients from the Bahamas." SpringerLink, Springer US, 14 Sept. 2010, DOI: https://doi.org/10.1007/s10549-010-1156-9.

${ }^{39}$ Dunn details the scandals that plagued Black leaders in the 1970s. Graham was forced to resign from his commissioner's position in a bribery zoning scandal in May of 1975. While the conviction was overturned by the State Supreme Court in 1978, Dunn argues that the damages to his reputation were irreparable and he died in obscurity in March of 1987 (255). See also Rose.
} 
In foregrounding the life writings of Black academics, we understand that the insights provided here slant toward those who now occupy middle-class positions, and even comprise an intellectual elite. "Looking for Black Miami," nevertheless seeks to both join and inaugurate other conversations on the dynamic quotidian Black life-worlds of this Hemispheric Southern city.

The essays that follow offer a mapping of Miami's diverse hemispheric Blackness: it is multi-classed; African American, dual-heritage Afro-Bahamian and African American, Black Cuban, St. Kittsian, Haitian, Jamaican, and an infinite number of other mixtures. Germane Barnes's photo essay chronicles changing Black Miami architecture as the buildings themselves reflect the city's political and social transformations. Tera Hunter's opening essay, "Black Miami to Me," reflects on her family's South to South intraregional 1950s migration from rural Georgia to Miami rather than the more typical Great Migration to the North. Where her parents' generation could reasonably expect job growth and opportunity, subsequent generations of Blacks in Miami experienced new forms of racial restrictions in labor force practices that hire co-ethnics and privilege bilingual Spanish speakers. Next, in "There's a Part of Me That Must Remain Truthful to the Story," Juana Valdes frames her Black Cubanidad as at once a visual and sonic dissonance that she lives as a permanent structure of feeling as a Black Cuban in the U.S. and particularly a Black Cuban visual artist in Miami. Kevin Quashie's "Queer. Caribbean. Miami. Boy: A Personal Geography" is a mapping of coming out/of age organized around Black queer male desire and finding home in the sounds and rhythms of 1980s R\&B. Edda Fields-Black's "The Smallness of Identity, Smallness of Blackness" writes against racial or ethnic exceptionality by locating herself as intimately shaped by Miami's Bahamian, African American, and Latinx communities, and the similarities of their prejudices and exclusionary practices. Jemima Pierre's "Haitian in Black Miami: A Narrative in Three Acts" is a spiritual, geographical, and cultural charting of Miami: of its violent distribution of amenities along racial lines; of a specific Black ethnic community finding its way in the face of tremendous odds; of the fraught emergence of complex Black interethnic identity formation. Where Pierre's essay ends with a sense of the inevitability of losing both her parents' church-which still bears her father's name, Delanot Pierre-and Little Haiti to gentrification, the inclusion of Marta Gierczyk's 2017-2019 ethnography captures the resistance being mounted by Haitian female civic leaders and their allies against the massive redevelopment initiatives in Little Haiti. These female activists occupy a range of positions, at times oppositional, but nevertheless mobilize to stake their claim in what many believe are developers' ill-conceived plans reliant on special zoning concessions to rebrand Little Haiti "the Magic City corridor"-a speculation that this area of the city, ten feet above sea-level, will house the next technology boom (Greene, Markowitz). Jafari Allen's afterword, "Miami's Nappy Edges: Finding Black Miami, Sin Fronteras," reflects on how each writer clarifies the complex iterations of anti-Black practices in this city and what this journal issue offers the future of Black Studies. The essays in this collection traverse the city, looping through Black neighborhoods from north to south to offer a retrospective diagramming of a metropolis constantly in flux.

In a city built on speculation, these many entanglements led to the senior author's own speculation on Blackness. In other words, it both anticipates and answers Nathan Connolly's questions: "What kinds of real-world happenings can be born of our experiences and research questions? What's the transformative potential of the Miami in our intellectual personalities?" The optimistic speculation is that in bringing together the many Black communities reflected here, we not only capture, render visible, and archive the multifaceted Black geographies in Miami-Dade County, but we also bring these various Black ethnicities into a fulsome conversational whole to advocate for collective practices that will secure the good life for the many, rather than the few. We offer these essays in the spirit of a larger intellectual commitment to tell more complex and compelling histories of Black living in Miami.

\section{Competing Interests}

The authors have no competing interests to declare.

\section{References}

Aja, Allan. Miami's Forgotten Cubans: Race, Racializaton, and the Miami Afro-Cuban Experience. Palgrave Macmillan, 2016. DOI: https://doi.org/10.1057/978-1-137-57045-1

Anderson, Glenn. "Florida's Bahamian Connection." Florida Geographer vol. 27, 1996, pp. 68-80.

Aranda, Elizabeth, Sallie Hughes and Elena Sabogal. Making a Life in Multiethnic Miami: Immigration and the Rise of a Global City. Lynne Rienner Publishers, 2014.

Barnes, Germane. "[Housing] Destruction." Journal of Architectural Education, vol. 72, no. 1, 2018, pp. 20-21. DOI: https://doi.org/10.1080/10464883.2018.1410641 
Benson, Devyn Spence. AntiRacism in Cuba: The Unfinished Revolution. The University of North Carolina Press, 2016.

Bettinger-Lopez, Caroline. Cuban Jewish Journeys: Searching for Identity, Home, and History in Miami. The University of Tennessee Press, 2000.

Boyce Davies, Carole. Caribbean Spaces: Escapes from Twilight Zones. University of Illinois Press, 2013. DOI: https://doi.org/10.5406/illinois/9780252038020.001.0001

Burch, Audra. "On the Front Porch, Black Life in Full View." The New York Times, 4 Dec. 2018. www.nytimes. com/2018/12/04/us/porch-detroit-black-life.html.

Bush, Gregory. White Sand, Black Beach: Civil Rights, Public Space, and Miami's Virginia Key. University Press of Florida, 2016. DOI: https://doi.org/10.5744/florida/9780813062648.001.0001

Campbell, Luther. The Book of Luke: My Fight for Truth, Justice, and Liberty City. Amistad Press, 2015.

Campbell, Marvin. The View from Key West: Toward a Global South Atlantic Lyric. 2015. University of Virginia, PhD dissertation.

Cassanello, Robert, and Daniel S. Murphree. "The Epic of Greater Florida: Florida's Global Past." The Florida Historical Quarterly, vol. 84, no. 1, 2005, pp. 1-9.

Clealand, Danielle Pilar, and Devyn Spence Benson. Black Migration Into a White City: Power, Privilege and Exclusion in Cuban Miami. Forthcoming.

Connolly, N. D. B. A World More Concrete: Real Estate and the Remaking of Jim Crow South Florida. University of Chicago Press, 2014. DOI: https://doi.org/10.7208/chicago/9780226135250.001.0001

Corben, Billy, and Alfred Spellman. The U: An ESPN 30-for-30. Rakontur Films, 2009.

Due, Tananarive, and Patricia Stephens Due. Freedom in the Family: A Mother-Daughter Memoir of the Fight for Civil Rights. One World Book, 2003.

Dunn, Marvin. Black Miami in the Twentieth Century. University Press of Florida, 2016.

Fields-Black, Edda. Deep Roots: Rice in West Africa and the African Diaspora. Indiana University Press, 2008.

Francis, Donette. "Juxtaposing Creoles: Miami in the Plays of Tarell Alvin McCraney." Tarell Alvin McCraney. Theater, Performance, and Collaboration, edited by Sharrell D. Luckett, David Román, and Isaiah Matthew Wooden. Evanston: Northwestern University Press, 2020.

Garrett, Patricia Harper, and Jessica Garrett Modkins. Miami's Richmond Heights. Arcadia Publishing, 2013.

Gosin, Monika. The Racial Politics of Division: Interethnic Struggles for Legitimacy in Multicultural Miami. Ithaca and London: Cornell University Press, 2019. DOI: https://doi.org/10.7591/9781501738258

Greene, Nadege. There Goes the Neighborhood. Miami. WLRN Presents.

Griffin, Farah Jasmine. "Who set you Flowin'?": The African-American Migration Narrative. Oxford University Press, 1995. DOI: https://doi.org/10.1093/acprof:oso/9780195088960.001.0001

Hunter, Marcus, and Zandria F. Robinson. Chocolate Cities: The Black Map of American Life. University of California Press, 2018. DOI: https://doi.org/10.1525/california/9780520292826.001.0001

Hunter, Tera W. To 'Joy My Freedom: Southern Black Women's Lives and Labor After the Civil War. Harvard University Press, 1997.

Jack, Anthony. The Privileged Poor: How Elite Colleges are Failing Disadvantaged Students. Cambridge, Mass: Harvard UP, 2019. DOI: https://doi.org/10.4159/9780674239647

Jack, Anthony Abraham. "On Her Behalf: James Baldwin, Family, and Educational Inequality." Common Reader, vol. 4, no. 1, 2019, pp. 19-38.

Jacoby, Susan. "The 350,000 Cubans in South Florida Make A Remarkable Success Story." New York Times, Sept. 29, 1974.

Keenan, Jesse M., Thomas Hill, and Anurag Gumber. "Climate Gentrification: From Theory to Empiricism in Miami Dade County, FL." Environmental Research Letters, vol. 13, no. 5, 2018. DOI: https://doi. org/10.1088/1748-9326/aabb32

Kokomoor, Kevin. "A Re-assessment of Seminoles, Africans and Slavery on the Florida Frontier." The Florida Historical Quarterly, vol. 88, no. 2, Fall 2009, pp. 209-236.

Lopez, Antonio. Unbecoming Blackness: The Diaspora Cultures of Afro-Cuban America. NYU Press, 2012. DOI: https://doi.org/10.18574/nyu/9780814765463.001.0001

Marable, Manning. "The Fire This Time: The Miami Rebellion, May, 1980." The Black Scholar, July-August 1980, pp. 2-18. DOI: https://doi.org/10.1080/00064246.1980.11414129

Markowitz, Douglas. "Will Allapattah Fall Victim to the Gentrification that Claimed Wynwood." Miami New Times, December 3, 2019.

Merrick, George. "Pre-Flagler Influences on the Lower Florida East Coast." Tequesta, vol. 1, no. 1, 1941, pp. 1-10. Miami Herald. Flashback Miami: School Integration. flashbackmiami.com/2014/05/14/school-integration/. 
Mohl, Raymond A. "On the Edge: Blacks and Hispanics in Metropolitan Miami Since 1959," The Florida Historical Quarterly, vol. 69, no. 1, July 1990, pp. 37-56.

Mohl, Raymond A. "'South of the South?' Jews, Blacks, and the Civil Rights Movement in Miami, 1945-1960." Journal of American Ethnic History, vol. 18, no. 2, 1999, pp. 3-36.

Mohl, Raymond A. "Whitening Miami: Race, Housing and Government Policy in Twentieth-Century Dade County." The Florida Historical Quarterly, vol. 79, no. 3, 2001, pp. 319-345.

Niman, Jan. Miami: Mistress of the Americas. University of Pennsylvania Press, 2011. DOI: https://doi. org/10.9783/9780812207026

Pierce, F. A. "The Sponge Industry in the Americas." Bulletin of the Pan American Union. Washington Government Printing Office, 1911.

Pierre, Jemima. The Predicament of Blackness: Postcolonial Ghana and the Politics of Race. University of Chicago Press, 2012. DOI: https://doi.org/10.7208/chicago/9780226923048.001.0001

Portes, Alejandro, and Alex Stepick. City on the Edge: The Transformation of Miami. University of California Press, 1993.

Portes, Alejandro, and Ariel C. Armony. The Global Edge: Miami in the Twentieth-First Century. University of California Press, 2018. DOI: https://doi.org/10.1525/california/9780520297104.001.0001

Quashie, Kevin. The Sovereignty of Quiet: Beyond Resistance in Black Culture. Rutgers University Press, 2012.

Rivero, Yeidy M. "Channeling Blackness, Challenging Racism: A Theatrical Response." Global Media and Communication, vol. 2, no. 3, Dec. 2006, pp. 335-354. DOI: https://doi.org/10.1177/1742766506069582

Rose, Chanelle Nyree. The Struggle for Black Freedom in Miami: Civil Rights and America's Tourist Paradise: 1896-1968. LSU Press, 2015.

Shell-Weiss, Melanie. "Coming North to the South: Migration, Labor and City-Building in Twentieth-Century Miami." The Florida Historical Quarterly, vol. 84, no. 1, 2005, pp. 79-99.

Stuart, John. "Liberty Square: Florida's First Public Housing Project." The New Deal in South Florida, edited by John F. Stack and John A. Stuart. University Press of Florida, 2008.

The Color of Wealth. The Kirwan Institute for the Study of Race and Ethnicity at The Ohio State University, the Samuel DuBois Cook Center on Social Equity at Duke University, and the Insight Center for Community Economic Development. Contributors: Alan A. Aja, Khaing Zaw, Gretchen Beesing, Anne E. Price, Daniel Bustillo, William Darity, Jr, Danielle Clealand, Mark Paul, Darrick Hamilton. 2019. //kirwaninstitute.osu. edu/the-color-of-wealth-in-miami/.

Trouillot, Michel-Rolph. "Culture on the Edges: Creolization in the Plantation Context." The African Diaspora and Creolization Literary Forum. Broward County, FL: A.C.T.I.O.N. Foundation, Inc, 2006, pp. 9-21.

Winsboro, Irvin D. S., and Abel A. Bartley. "Race, Education, and Regionalism: The Long and Troubling History of School Desegregation in the Sunshine State." The Florida Historical Quarterly, vol. 92, no. 4, 2014, pp. 714-745.

How to cite this article: Francis, D and Harris, A 2020 Introduction: Looking for Black Miami. Anthurium, 16(1): 2, 1-17. DOI: https://doi.org/10.33596/anth.408

Published: 31 March 2020

Copyright: $\odot 2020$ The Author(s). This is an open-access article distributed under the terms of the Creative Commons Attribution 4.0 International License (CC-BY 4.0), which permits unrestricted use, distribution, and reproduction in any medium, provided the original author and source are credited. See http://creativecommons.org/licenses/by/4.0/. 